\title{
Ideological Disempowerment of Teachers
}

\author{
Kwok Kuen Tsang (Beijing Normal University)
}

Since the 1990s, school education systems have been dominated by managerialism in different parts of the world (Ball, 1994; Besley, 2019; Darling-Hammond, 2004; Mok, 2003). The literature has suggested that managerialism is a cultural pressure (Hallett \& Meanwell, 2016), which structurally disempowers teachers in teaching (Anagnostopoulos, 2003; Comber \& Nixon, 2009; Hargreaves, 1994; Helsby, 1999; Morris, 2004; O'Brien \& Down, 2002; Robertson, 2000; Smyth, Dow, Hattam, Reid, \& Shacklock, 2000). It shows that the cultural pressure creates social criticism and distrust against the professionalism of teachers and legitimizes the introduction of accountability measures like school choice, performance indicators, and league table for monitoring and supervising teachers' work (Apple, 1982; Berliner \& Biddle, 1995). As a result, teachers gradually lose power and autonomy in controlling their labor and labor process which become subject to external control from the government, school administrators, educational experts, and the public (Smyth et al., 2000). In such a condition, they tend to be forced to do much administrative and non-instructional work, which they disvalue but are powerless to reject (Apple, 1986; Ball, 2003; Hargreaves, 1994; Penrice, 2011; Smyth et al., 2000) leading to stress, demoralization, and different kinds of emotional experiences affecting their mentality and well-being (Santoro, 2011; Saunders, 2013; Trentini, 2012; Zembylas, 2011).

To criticize the deleterious effects of managerialism to teachers' work, mentality, and well-being, education researchers use the concept like deskilling (Apple, 1986), proletarianization (Densmore, 1987), and deprofessionalization (Jeffrey \& Woods, 1996) to describe how managerialism disempowers teachers. However, I find that these existing concepts do not fully capture teacher disempowerment in the era of managerialism. To some extent, these concepts only focus on the technical dimension of teacher disempowerment defined as the deprivation of teachers' power over their labor and labor process. On the other hand, they do not recognize another dimension what I call ideological or cognitive disempowerment which is the deprivation of teachers' power to identify the meanings of their work (Tsang, 2019a). Therefore, I discuss and illustrate how managerialism ideologically disempowers teachers based on my previous research on Hong Kong secondary schoolteachers' emotional experiences (Tsang, 2017, 2019a, 2019b; Tsang \& Jiang, 2018; Tsang \& Kwong, 2016, 2017; Tsang \& Liu, 2016) in this short essay in an attempt to enhance our understandings of teacher disempowerment in the era of managerialism.

\section{Ideological Disempowerment}

As the literature suggests (e.g., Hargreaves, 1994; Smyth et al., 2000), my research shows that managerialism did technically disempower Hong Kong teachers in the labor process through the introduction and implementation of accountability measures. As predicted, the technically disempowered teachers were restricted to determine what, how, and when to do their work in teaching resulting in intensification of what they called non-instructional work. In addition to stress and exhaustion, my research findings also indicate that the intensification of non-instructional work made the Hong Kong teachers feel meaningless, frustrated, demoralized, and other negative emotions in teaching, because they were overwhelmed by the non-instructional work leading to the lack of time and energy to instructional work.

However, it is not the whole story. According to my research, the Hong Kong teachers' negative emotional experiences also relates to how they interpreted the meanings of their work. As the above discussion implies, the teachers generally categorized their work into instructional and non-instructional work. They often complained about how the heavy non-instructional workload eroded and drained their time and energy for instructional work. However, what kinds of work were perceived as instructional and non-instructional work by the teachers? According to them, instructional work included the duties like classroom teaching, lesson preparation, marking, formal and informal interaction with students, while non-instructional work included the duties like organizing educational programs and extracurricular activities outside classroom, meetings, and paperwork. Most of the teachers mentioned that organizing educational programs and extracurricular activities accounted for a large proportion of noninstructional work. Nevertheless, to many people (e.g., Kennedy, 2005), including me, educational programs and extracurricular activities should be instructional in nature. Therefore, I was surprised when I heard that the teachers were dissatisfied with the educational programs and 
extracurricular activities because they saw the work were non-instructional instead of instructional.

Why did the teachers not identify the instructional meanings of the so-called "non-instructional work"? According to my research, the answer is related to ideological disempowerment. It means that the teachers were ideologically disempowered by managerialisms which structurally displaced the instructional meanings and values of the work with the administrative meanings and values via accountability measures like performance indicators and parent choice. In Hong Kong, the government has developed performance indicators for the evaluation of school quality and effectiveness. According to the performance indicators framework (Education Department, 2002), Hong Kong schools have to prove their performance in the domains of student support and school ethos (e.g., support for student development) and student performance (e.g. students' affective development and social development). To prove their performance in the domains, the schools push teachers to organize educational programs and extracurricular activities as much as possible. As a teacher said,

[The] EBD (Education Bureau) has four domains for reviewing a school and one is student support. The categories of teacher performance, guidance, extracurricular activities and civil education constitute students' growth. That is to say, the more extracurricular activities we organise, the better we can prove we provide good support for students' growth. (Connie)

Therefore, some of the teachers may believe that they are forced to do this work not to facilitate students' development, but for the administrative welfare of the schools, i.e., meeting the requirements of performance indicators.

In addition, the schools are pressured to treat the educational programs and extracurricular activities as the "selling point" to attract more parents and students. This situation occurs because, due to the decline in the student population, the government announces its intention to close schools that cannot recruit enough students in the spirit of parent choice. To survive, schools acted strategically and began to forcefully pursue good images to attract students.

If a school needs to attract students, it usually designs banners to display how great its academic results and extra-curricular activities are. The school would also market its clubs, in particular emphasizing what awards are attained by certain clubs and sports teams. If a school emphasizes achievement too much, it would probably push its students to earn more awards. Yet, how do we get more awards? The answer is by pushing students to take part in an overwhelming number of activities and amount of training to achieve good results. This is particularly helpful in building up school image and increasing student admission numbers. (Eva)

Last but not least, since the teaches are accountable for their performance in organizing the educational programs and extracurricular activities, they had to do a lot of administrative work when they organized such programs and activities. For instance,

We need to write reports and plans. In fact, we really spend a lot of time on writing these. For instance, an annual report doesn't just take us a few hours of writing by the end of the school term, but it's a matter of the whole school term. We have to do evaluation after each activity, such as spreading questionnaires to and collecting the opinion from the students, teachers and parents. All data collected and all evaluation materials should be kept well as supporting documents in the reports...It is such a time consuming and tiring work. (Connie)

Accordingly, managerialism tends to extensively tie an abundance of administrative duties and values to the educational programs and extracurricular activities and ultimately displace the instructional goals of the programs and activities with administrative proposes via accountability measures. Therefore, this situation constrains the teachers' power to realize the instructional meanings of their work so that they may define the work as "non-instructional". This is what I call ideological disempowerment.

\section{Summary}

In this short article, I argued that managerialism does not only technically disempower, which may also be referred to as deskill, proletarianize and/or deprofessionalize, but also ideologically disempower teachers. The technically and ideologically disempowered teachers tend to become powerless to resist heavy administrative workload assigned by external agents and to realize the instructional meanings of the workload which should have instructional meanings in nature. As a result, the teachers may interpret they are stressed and exhausted to do many things irrelevant to education and in turn experience different kinds of negative emotions, which may affect their well-beings (Day \& Qing, 2009). Therefore, in addition to technical disempowerment, I call for more attention to be paid to the ideological disempowerment of teachers, which is understudied, in order to provide a more comprehensive understanding about the impacts of managerialism on teachers' lives, mentality, and well-being. 


\section{References}

Anagnostopoulos, D. (2003). The new accountability, student failure, and teachers' work in urban high schools. Educational Policy, 17(3), 291-316. https://doi.org/10.1177/0895904803017003001

Apple, M. W. (1982). Education and power. Boston, MA: Routledge \& Kegan Paul.

Apple, M. W. (1986). Teachers and texts: A political economy of class and gender relations in education. New York, NY: Routledge \& Kegan Paul.

Ball, S. J. (1994). Educational reform: A critical and post-structural approach. Buckingham: Open University Press.

Ball, S. J. (2003). The teacher's soul and the terrors of performativity. Journal of Education Policy, 18(2), 215-228. https://doi.org/10.1080/0268093022000043065

Berliner, D. C., \& Biddle, B. J. (1995). The manufactured crisis: Myths, fraud, and the attack on America's public schools. New York, NY: Addison-Wesley.

Besley, T. (2019). Theorizing teacher responsibility in an age of neoliberal accountability. Beijing International Review of Education, 1(1), 179-195. https://doi.org/10.1163/25902547-00101013

Comber, B., \& Nixon, H. (2009). Teachers' work and pedagogy in an era of accountability. Discourse: Studies in the Cultural Politics of Education, 30(3), 333-345. https://doi.org/10.1080/01596300903037069

Darling-Hammond, L. (2004). Standards, accountability, and school reform. Teachers College Record, 106(6), 1047-1085.

Day, C., \& Qing, G. (2009). Teacher emotions: Well being and effectiveness. In P. A. Schutz \& M. Zembylas (Eds.), Advances in teacher emotion research: The impact on teachers' lives (pp. 15-31). https://doi.org/10.1007/978-1-44190564-2 2

Densmore, K. (1987). Professionalism, proletarianization and teacher work. In T. S. Popkewitz (Ed.), Critical studies in teacher education: Its folklore, theory and practice (pp. 130-160). London: Falmer.

Education Department. (2002). Performance indicators for Hong Kong schools: Evidence of performance. Hong Kong: Government Printer.

Hallett, T., \& Meanwell, E. (2016). Accountability as an inhabited institution: Contested meanings and the symbolic politics of reform. Symbolic Interaction, 39(3), 374-396. https://doi.org/10.1002/SYMB.241

Hargreaves, A. (1994). Changing teachers, changing times: Teachers' work and culture in the postmodern age. London: Cassell.

Helsby, G. (1999). Changing teachers' work: The 'reform' of secondary schooling. Buckingham: Open University Press.

Jeffrey, B., \& Woods, P. (1996). Feeling deprofessionalised: The social construction of emotions during an OFSTED inspection. Cambridge Journal of Education, 26(3), 325-345. https://doi.org/10.1080/0305764960260303

Kennedy, K. J. (2005). Changing schools for changing times: New directions for the school curriculum in Hong Kong. Hong Kong: Chinese University Press.

Mok, K. H. (Ed.) (2003). Centralization and decentralization: Educational reforms and changing governance in Chinese societies. Hong Kong: Comparative Education Research Centre, The University of Hong Kong.

Morris, P. (2004). Teaching in Hong Kong: Professionalization, accountability and the state. Research Papers in Education, 19(1), 105-121. https://doi.org/10.1080/0267152032000177007

O'Brien, P., \& Down, B. (2002). What are teachers saying about new managerialism? Journal of Educational Enquiry, 3(1), $111-133$.

Penrice, G. (2011). The effects of intensification on rural teachers' work. New Zealand Journal of Teachers' Work, 8(2), 104113.

Robertson, S. L. (2000). A class art: Changing teachers' work, the state, and globalisation. New York, NY: Falmer.

Santoro, D. A. (2011). Good teaching in difficult times: Demoralization in the pursuit of good work. American Journal of Education, 118(1), 1-23. https://doi.org/10.1086/662010

Saunders, R. (2013). The role of teacher emotions in change: Experiences, patterns and implications for professional development. Journal of Educational Change, 14(3), 303-333. https://doi.org/10.1007/s10833-012-9195-0 
Smyth, J., Dow, A., Hattam, R., Reid, A., \& Shacklock, G. (2000). Teacher's work in a globalizing economy. London: Falmer.

Trentini, M. (2012). Teaching and the transmutation of emotions. International Journal of Work Organisation and Emotion, 5(2), 178-192. https://doi.org/10.1504/IJWOE.2012.049520

Tsang, K. K. (2017). Exploring teachers' work and emotional experiences in Hong Kong: A qualitative study. In A. M. Columbus (Ed.), Advances in psychology research (pp. 127-156). New York, NY: Nova Science.

Tsang, K. K. (2019a). Teachers' work and emotions: A sociological analysis. London: Routledge.

Tsang, K. K. (2019b). Teachers as disempowered and demoralised moral agents: School board management and teachers in Hong Kong. British Journal of Educational Studies, 67(2), 251-267. https://doi.org/10.1080/00071005.2018.1497770

Tsang, K. K., \& Jiang, L. (2018). Positive emotional experiences in teaching, teacher identity, and student behavior: A symbolic interactionist perspective. Schools: Studies in Education, 15(2), 228-246. https://doi.org/10.1086/699890

Tsang, K. K., \& Kwong, T. L. (2016). Emotional experience of $\mathrm{Caam}^{2}$ in teaching: Power and interpretation of teachers work. Frontiers in Psychology, 7, 1400. https://doi.org/10.3389/fpsyg.2016.01400

Tsang, K. K., \& Kwong, T. L. (2017). Teachers' emotions in the context of education reform: Labor process theory and social constructionism. British Journal of Sociology of Education, 38(6), 841-855.

https://doi.org/10.1080/01425692.2016.1182007

Tsang, K. K., \& Liu, D. (2016). Teacher demoralization, disempowerment and school administration. Qualitative Research in Education, 5(2), 200-225. https://doi.org/10.17583/qre.2016.1883

Zembylas, M. (2011). Teaching and teacher emotions: A post-structural perspective. In C. Day \& J. C.-K. Lee (Eds.), New understandings of teacher's work: Emotions and educational change (pp. 31-43). https://doi.org/10.1007/978-94-0070545-6_3

\section{Recommended Citation}

Tsang, K. K. (2019). Ideological disempowerment of teachers. On Education. Journal for Research and Debate, 2(5). https://doi.org/10.17899/on_ed.2019.5.5

About the Author

Kwok Kuen Tsang is an Associate Dean and Assistant Professor at the College of Education Administration at Beijing Normal University. His research focuses on teachers' work and emotions, educational change and reform, and school organization. 